Int. J. Electrochem. Sci., 13 (2018) 250 - 264

International Journal of

ELECTROCHEMICAL

SCIENCE

www.electrochemsci.org

\title{
Corrosion Inhibition Behavior of 9-Hydroxyrisperidone as a Green Corrosion Inhibitor for Mild Steel in Hydrochloric Acid: Electrochemical, DFT and MD Simulations Studies
}

\author{
H. Lgaz, ${ }^{1,2}$, R. Salghi ${ }^{1, *}$, Ismat H. Ali ${ }^{3, *}$ \\ ${ }^{1}$ Laboratory of separation processes, Faculty of Science, University Ibn Tofail PO Box 242. Kenitra, \\ Morocco. \\ ${ }^{2}$ Laboratory of Applied Chemistry and Environment, ENSA, University Ibn Zohr, PO Box 1136. \\ Agadir, Morocco. \\ ${ }^{3}$ Department of Chemistry, College of Science, King Khalid University, P. O. Boox, Postal Code \\ 61413, Saudi Arabia \\ *E-mail: ismathassanali@gmail.com; r.salghi@uiz.ac.ma;
}

doi: $10.20964 / 2018.01 .26$

Received: 22 August 2017 / Accepted: 27 October 2017 / Online Published: 1 December 2017

\begin{abstract}
A green corrosion inhibitor namely, 9-Hydroxyrisperidone (HRD) was investigated for their influence on mild steel corrosion in $1 \mathrm{M} \mathrm{HCl}$ using weight loss, Tafel polarization, electrochemical impedance spectroscopy (EIS) and surface morphology techniques. Quantum chemical calculations were also conducted to corroborate experimental findings. The tested compound is mixed type inhibitor following Langmuir adsorption isotherm and involved competitive physisorption and chemisorption mechanisms. The results from electrochemical impedance spectroscopy tests reveal an increase in polarization resistance. Scanning Electron Microscopy (SEM) analyses of steel surfaces in acidinhibitor solutions showed that tested compound protects mild steel surface effectively. The inhibition property was further elucidated by theoretical approaches; quantum chemical calculation and Molecular Dynamic (MD) simulation.
\end{abstract}

Keywords: Inhibition, Corrosion, 9-Hydroxyrisperidone, Steel, DFT, Molecular Dynamic.

\section{$\underline{\text { FULL TEXT }}$}

(C) 2018 The Authors. Published by ESG (www.electrochemsci.org). This article is an open access article distributed under the terms and conditions of the Creative Commons Attribution license (http://creativecommons.org/licenses/by/4.0/). 